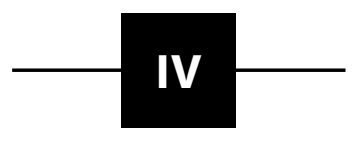

\title{
TEACHING
}

\section{How to Conceptualize an Introductory Course on the Academic Study of Religion Systematic Reflections and Exemplary Answers}

\author{
Johannes Quack
}

ABSTRACT: How should instructors conceptualize an introductory course on the academic study of religion? This article combines an abstract and broader review of different conceptualizations of such courses with hands-on discussions of two exemplary teaching models. The 'case study model' applies different approaches within the study of religion to a single case study in order to exemplify and compare their potentials and limitations. The 'monograph model' illustrates how an ethnography is used as a reference point for a discussion of the history of and current strands within the study of religion. Both models are particularly well suited to facilitate the combination of an overview of key themes, approaches, terms, and scholars with a close study of the intricate and captivating empirical reality of 'lived religion(s)'.

KEYWORDS: anthropology, discipline, ethnography, introduction, lived religions, modernity, syllabus, teaching

Introductory courses are the pinnacle of the teacher's craft. The complexity of their construction is akin to composing symphonies or operas, provided instructors are not simply whistling their own tune, that is, not simply talking about matters close to their own thematic and theoretical interests. An overview tuned into the multi-voiced history of roughly 150 years of scholarly debate requires priorities and balance. How exactly does one choose and arrange distinct voices and approaches? What should be the leitmotif? On which key aspects should the lecture be based? How canonical or vanguard should it be? How can it provide an abstract overview of theories and schools of thought without losing sight of everyday practices and real-life concerns? How can an introductory lecture make students aware of the relevance of disciplinary history without smothering their curiosity? How can the dense composition be balanced with space for student-centered interaction and improvisation?

Although many colleagues are frequently confronted with such challenges, ${ }^{1}$ literature on these matters is available only in very general terms. ${ }^{2}$ To fill this gap, this article combines hands-on 
discussions of exemplary teaching experiences with a more abstract and broader review of different conceptualizations of introductory courses on the academic study of religion. It starts with an analysis of the ways in which introductory books for the study of religion are structured with a focus on texts that introduce the anthropological study of religion. Thereafter, two particularly fruitful models are introduced. First, a brief summary of the 'case study model' outlines how and why this model applies different approaches within the study of religion to a single case study (in this case the hajj pilgrimage) in order to exemplify their potentials and limitations. Second, a more extensive description of the 'monograph model' summarizes how a monograph-in this case, Nathaniel Roberts's (2016) ethnography To Be Cared For: The Power of Conversion and Foreignness of Belonging in an Indian Slum-is used as a reference point for a discussion of a set of key themes, scholars, and approaches situated within the history of the study of religion. The article concludes by summarizing how these two courses' combination of an overview of key themes, approaches, terms, and scholars with a coherent and closer study of the intricate empirical reality of 'lived religion(s)' makes them particularly well suited to provide an outline of the history of and current strands within the academic study of religion. It thereby seeks to contribute pragmatic solutions to problems that many scholars have observed before. Drawing on Manuel Vásquez (2010) and Michael Lambek (2008), Abby Day and Simon Coleman (2016: 211) note that a focus on the distant and abstract worlds of philosophy, theory, and theology may "obscure what is fascinating and important about lived religion."

\section{Different Ways to Conceptualize a Syllabus}

A systematic analysis of introductory books on the study of religion reveals different organizing principles. ${ }^{3}$ A rather abstract engagement discusses various definitions of religion (Saler 1993) and, for example, the notorious question of a presumed essence of religion. A much more concrete approach offers an introduction to a selection of religious traditions (Morris 2006), which might range from Alevism to Zoroastrianism. A combination of abstract and concrete inputs is facilitated by focusing on key topics from the anthropology of religion (Bowie 2005), including, among others, ancestor worship, magic, myths, and rituals. Fiona Bowie's introduction also addresses the silenced voices of women in the field and features a helpful appendix of visual resources (in addition to texts) that are particularly effective for teaching (ibid.). Jack Eller's (2015) introductory book likewise focuses on key topics but also includes more current debates in chapters such as "Religious Change and New Religious Movements," "Secularism and Irreligion," and "Religious Fundamentalism."

Others introduce the anthropology of religion through various scientific approaches or schools of thought and the primary protagonists who have presumably characterized the field. An extensive selection of classic texts is available as a reader (Lambek 2008), ${ }^{4}$ complemented with a compendium (Boddy and Lambek 2013). Additionally, some introductory books offer a chronological treatise (Morris 1987), which might range from Marx, Nietzsche, and the evolutionists of the nineteenth century to cognitivist, post-colonial, and other more recent approaches. An alternative to this is the systematization of the different theoretical approaches (Pals 2006). In such a perspective, one might group evolutionist and cognitive theories together with psychological approaches in order to compare them to sociological, phenomenological, or genealogical approaches.

Yet another organizing principle of an introduction to the academic study of religion provides the opportunity to debate the degree to which the different disciplinary methods and traditions can be distinguished. Questions as to whether anthropological research took place 
in societies in which no comparable concepts to the modern notion of religion were found can be addressed. This strengthens students' critical view on the range, importance, and political implications of the concept of 'religion', as well as the holistic claims of classical anthropology that different social fields (e.g., economy, politics, and religion) should not be distinguished $a$ priori. Additionally, an introductory course can contextualize inter- and intra-disciplinary differences with respect to methodologies and the emphasis of written, philosophical, and theological reflections on religion or the actual engagements with ordinary or 'lay' actors' everyday practices of lived religions.

As illustrated further below, all these approaches have advantages and disadvantages. Some are systematically structured around theories or viewpoints, others focus on key terms, influential scholars, empirical case studies, or particular religious traditions, and some try to give a sense of the historical development of the interdisciplinary study of religion. Course evaluations show that individual students prefer different thematic orientations and systematic structures. To reach as wide a student base as possible, the two models introduced in the next section do not opt for a single organizing principle but combine most of the elements mentioned above. Both models trace historical developments and introduce leading scholars, influential debates, and key terms. They also engage with abstract questions of definitions and different disciplinary approaches to the study of religion through in-depth engagement with lived religions, drawing on examples from one or two established religious traditions.

\section{Case Study Model and Monograph Model}

\section{Case Study Model}

All teaching is historically and regionally situated; it is embedded in specific curricular arrangements and local interpretations of disciplinary traditions as well as the larger politics of academic work. ${ }^{5}$ Jens Kugele brought the 'case study model' to my attention while he was teaching at the University of Munich, which offers a non-denominational Interfaculty Programme for the Study of Religion that engages historically and comparatively with various religious traditions. The program has been well known in Germany for its ambitious first-year introductory course since it was developed by Jürgen Mohn and Gregor Ahn at the turn of the millennium, and later refined by Anne Koch and Alexandra Grieser. On this basis, Kugele reconceptualized the course in 2009 and consecutively reworked and taught it together with Katharina Wilkens. In the following, I present my interpretation of the rationale behind Kugele's proposition to introduce a specific case study in introductory courses.

Two things are crucial to providing students with basic knowledge about the academic study of religion. First, students should be able to understand the disciplinary history not merely as a sequence of largely obsolete approaches that have been replaced by better options, but as an accumulation and plurality of more or less simultaneous yet nevertheless historically situated perspectives. Accordingly, introductory courses should catalyze students' critical thinking about why some ideas, methods, and approaches prevail or mutate or have been-for good reasons-largely put to rest. The development of evolutionary approaches from the end of the nineteenth century to the early twenty-first century, in combination with insights from biology and psychology, is a good example here. Second, students should understand what the different approaches to the study of religion enable us to investigate and what their respective strengths and shortcomings are. More abstractly, the goal is to establish an archaeology of thought and knowledge within the study of religion. 
To productively combine these two goals without losing sight of the students' curiosity, this model proposes a 'problem-oriented narrative' that analyzes a single illustrative case study throughout the course. Different approaches and perspectives are applied to the case study in chronological order of their emergence and heyday. On this basis, discussions of disciplinary history can be combined with a critical contextualization of the strengths and weaknesses of particular approaches. Kugele explained why he chose the hajj to me by highlighting that it constitutes a particularly multifaceted ritual complex that allows for an illustration of the potential of psychological, anthropological, sociological, geographical, economic, political, and aesthetical approaches. It also engages with many more aspects, such as filmic representations of religion, architecture, clothing, cultural imagination, text, and social practice. Moreover, using one illustrative example throughout the semester fosters course coherence, and, in Kugele's experience, clearly demonstrates the variety of possible approaches to 'religion(s)' and where perspectives are distinct from each other, where entirely different aspects come into focus, and where seemingly different perspectives might overlap.

Students thereby become familiar with the hajj through a wide variety of methodological and theoretical lenses. This enables them to compare how different approaches are applied and the insights that they foster, as well as their blind spots. Students also acquire the practical understanding (not just the 'dry' theory) of how certain insights are preconfigured by how the object of inquiry is approached in the first place. A further learning outcome is increased competences, not only in terms of having the ability to assess different approaches' strengths and weaknesses but also in being able to situate them within the history of the academic study of religion (and beyond), including the impact and exaggerations of various 'turns', such as the cultural, material, performative, spatial, visual, and ontological turn.

Accordingly, students learn how the approaches, as well as their findings, are embedded in historical, regional, and disciplinary discourses alongside the respective politics of knowledge. Such insights should enable them to adequately enter the academic study of religion as accepted representatives of their discipline.

\section{Monograph Model}

The second example draws on my experiences in the Department of Social Anthropology at the University of Zurich where an introductory course to the study of religion is taught alongside introductory courses to economics and ecology, kinship and gender, politics and law, and material culture and art (second- and third-year Bachelor of Arts). In all these courses, students are required to read a book-length ethnography alongside other course material, as the Department considers ethnographies the hallmark and crux of social anthropology. Despite the apparent decline in the reading and writing of complete books, the intricacy of many issues demands book-length arguments. And students can then apply the tools and strategies they use to dissect the more complex monograph to other academic genres.

Moreover, monographs, particularly ethnographies, help instructors in at least two ways. First, somewhat similar to the 'case study model', they enable teachers to interrelate different topics and teaching sessions rather than treating them as bounded and self-contained blocks. Second, many monographs confront students with intriguing, relevant, genuine, real-life concerns that challenge them to question their presuppositions, rethink prior assumptions, and come up with new ideas. Additionally, most ethnographies not only offer detailed knowledge about individual case studies, but also combine a thorough study of 'small places' with the discussion of 'large issues', as Thomas Hylland Eriksen ([1995] 2015) suggests in his introductory book on social and cultural anthropology. 
After testing a couple of different ethnographies, I chose Nathaniel Roberts's (2016) To Be Cared For. It describes and analyzes practices of religious conversion of Dalits (formerly 'untouchables') in a 'slum'6 in South India, which he refers to as Anbu Nagar. The ethnography's central themes are situated in a historical discussion of caste and religion in post-colonial India and contemporary national discourses on conversion, which are dominated by Indian 'elites.?

In addition to fitting my own areas of expertise, the book won me over because it is extremely well written and accessible for students and non-specialists without compromising on depth and engagement with multifaceted debates. It captivatingly introduces the general matters at stake and provides detailed descriptions of important particularities. Moreover, based on thorough and long-term ethnographic fieldwork, it contains vivid descriptions of two religious traditions, Christianity and Hinduism. It accordingly helps many students critically examine a relatively familiar religious tradition while they gain insight into a tradition that would be somewhat alien to most of them. The book also presents a rigorous scholarly analysis that is sensitive, respectful, and sympathetic all at the same time. It fosters students' understanding of how issues like gender, kinship, economy, and local as well as national politics are deeply intertwined with religious matters-for example, more married women convert to Christianity due to gendered income and debt structures-and are sometimes inseparable in the first place. ${ }^{8}$

In the following sections, I detail how I use the ethnography practically, beginning with a straightforward outline of my syllabus. This is followed by more abstract descriptions of the themes that run through many of my weekly sessions, including the implications of definitions, religion and modernity, and different disciplinary approaches toward and questions of decolonialization.

Outline of syllabus. This course takes place over 14 weekly 90 -minute sessions, addressing between 60 and 80 students. Each session is based on the students' reading of original texts and answers two guiding questions (see below). In the subsequent discussion we often interrogate the suitability of the questions themselves.

The key readings and the weekly lectures are chronologically organized and separated into three blocks. The first block (weeks 2 to 4 ) focuses on influential approaches, key terms, and debates in the history of the study of religion. During the second block (weeks 5 to 7 ), the lectures primarily engage with the ethnography To Be Cared For. The last block (weeks 8 to 12) introduces approaches and debates that are of major importance in the contemporary study of religion against the backdrop of the ethnography.

Issues of gender and post-coloniality are not addressed in separate sections but run throughout the course as a whole. With respect to the theme of decolonizing syllabi, and canonical texts in particular, I still struggle with balancing my aim to make students read influential scholars' works with how I include alternative voices and perspectives (without escalating the level of reading for the students).

1. Introduction: Why and how do we teach the anthropology of religion? Why did I compose the syllabus the way I did?

2. Definitions and Their Dis/Advantages: What is religion? Do all humans have religion?

3. Religion, Magic, and Modernity: What is the difference between magic and religion? Why do we discuss religion and modernity together?

4. Ritual, Rationality, and Ethnography: Are religious beliefs and practices irrational? Are there different rationalities at stake?

5. Disciplinary Differences: How do different disciplines approach religion? How do different anthropologists research religion?

6. Contested Borders: Why are the borders between religious traditions contested? What is the relationship between religion, caste, class, and race? 
7. Contested Practices: What is the difference between materiality and spirituality? What is the relationship between religion and ethics?

8. Religion as a Cultural System: What is a 'symbol system'? What are the many meanings of religious practices?

9. Colonialism, Orientalism, and Genealogy: Is 'religion' a Eurocentric term? What are its epistemological and political implications?

10. Body, Materiality, and Emotions: How is religion embodied and materialized? How does religion smell?

11. Secularization, Secularism, and Non-religion: Is religion losing importance? What would come after religion?

12. Cognition, Evolution, and Psychology-Again (see week 2): What is religion? Do all humans have religion?

13. Students attend a religious event (instead of reading a text and attending class). They write a short text in which they analyze their observations in light of one of the approaches discussed in the prior weeks.

14. Exam

While each weekly session is focused on a specific set of questions related to the key readings, many themes cut across the sessions. In the following, I provide a discussion of three such crosscutting themes.

Implications of definitions. James Bielo (2015: 2) has noted that he begins with definitions because whether and how scholars define religion "reveals important insights about their basic assumptions and commitments in the study of religion." In the first class, I ask students to note their understanding of 'religion', which I invite them to reconsider at the end of the term. The central expression that emerges in the initial definition is 'belief', generally in combination with 'God(s)' (or the like). Hence, it has proven fruitful to start (in week 2) with Sir Edward Tylor's ([1871] 2008: 23) classic and still prevalent 'minimum definition' of religion as a "belief in spiritual beings" and to discuss its subsequent modifications, for example, as "belief in supernatural beings" or "belief in non-empirical entities" (cf. Goody 1961; Spiro 1966). Since such definitions are very closely linked to how most students in my classes understand religion, these definitions help to question their (often) unreflective assumptions and to establish the basis for later discussions. Is religion necessarily based on belief? Is belief opposed to knowledge? And, if so, where should the line be drawn? Who decides what counts as belief or knowledge? Does religion necessarily concern something 'spiritual'? Is the core of religion invisible, intangible, internal, imagined, and irrational? What about 'material religion'? What is 'natural' if religion is supernatural? Where do such understandings of belief, spirituality, invisibility, and naturalness come from? What problems can be seen in the underlying dichotomies?

Subsequently, we engage (in week 3) with further definitions and related attempts to distinguish between religion and magic and to clarify the relationship between religion and ritual. Here, the focus is predominantly on Émile Durkheim's ([1912] 2001: 3) attempt to reach “an understanding of the religious nature of man, by showing us an essential and permanent aspect of humanity" via the study of "the most primitive and simplest religion," which he famously introduces with the following proposition (ibid.: 4):

The most barbarous or bizarre rituals and the strangest myths translate some human need, some aspect of life, whether individual or social. The reasons the believer uses to justify them may be, and generally are, mistaken; none the less, the true reasons exist, and it is the business of science to discover them. In reality, then, there are no false religions. All are true in their fashion: all respond, if in different ways, to the given conditions of human existence. 
This provides the grounds for many discussions to follow. Why and how does Durkheim grade religious traditions as 'primitive' or 'superior'? In what sense are all religions 'true'? Which 'human needs' need to be translated and which 'conditions of human existence' supposedly need an answer? We start such discussions, however, with the rather basic distinction between approaches that focus on the alleged 'substance' of religion compared to those more concerned with the 'function' of religion. For example, we look at how the 'substances' proposed as definiens of the definiendum 'religion', that is, God(s), spiritual beings, supernatural entities, or the sacred, frequently require explanations themselves and at times result in recursive definitions. The often proposed functions of religion-that it addresses alleged human needs by, for example, helping people cope with contingencies or that it unites communities or provides ultimate justifications - not only escalate the scope of the definition but also tend to ignore the many ways in which religion(s) may foster individual and social insecurity, disorder, and other sorts of malfunction.

Topics like these become particularly comprehensible if linked to real-life issues, for example, by discussing how such questions are grounded within the suggested ethnography (in weeks 5 to 7). First, Roberts (2016) forcefully outlines how the Indian elite discourse in general and lawmakers in particular assume that the main and positively valued function of religion lies in the unification of communities. This in turn is a major reason why the elites and lawmakers argue that religious conversion is "socially disruptive" (ibid.: 119). Roberts's ethnography shows, however, that this is not necessarily the case; conversions are not inevitably a threat to the public order in the communities in which they take place. Roberts found that "religion in the slum was not a matter of identity at all—neither national, ethnic, nor personal" (ibid.: 9), and that "slum dwellers identified individually as following one or the other of these mutually exclusive faiths" (ibid.: 153; original emphasis). Second, Roberts explains why and how people in the slum choose their religious practices primarily based on material concerns and worldly considerations. For them, Gods "existed to help people, and the benefits they provided were of a fundamentally worldly and moral, but not spiritual, nature. Neither Christianity nor Hinduism, as practiced in the slum, emphasized any sort of otherworldly telos" (ibid.: 9; original emphasis).

While he does not assume any simple differentiation between worldly, moral, and spiritual matters, Roberts (2016: 160) contends that the slum dwellers in Anbu Nagar inhabit a "theological realism" according to which Gods are causal forces "acting upon the world independently of human agency." Hence, they "were engaged in trying to find out which gods were real and therefore worth worshipping” (ibid.: 10). Such theological realism contrasts, according to Roberts, with both mainstream anthropological and elite Indian understandings of religion. He argues that most anthropologists are "theological nominalists" in the sense that they see "particular gods as intrinsically linked to the human traditions that worship them" (ibid.: 160). Evoking the great influence of a Durkheimian position within as well as outside of academia, ${ }^{9}$ Roberts notes: "Unlike the people of Anbu Nagar, anthropologists do not ask which religion (if any) is right, because anthropologically speaking all are equally true in their own terms. Gods are a cultural reality for anthropologists; they are a social fact, and, as such, are as real as anything else, so long as people worship and believe in them" (ibid.).

Roberts (2016: 16) further illustrates how the understanding of religion as spiritual, and therefore opposed to material (and political) concerns, is part of "the intellectual trajectory of the Indian independence movement," above all of Mohandas 'Mahatma' Gandhi's worldview. In this perspective, the slum dwellers are devalued as being not genuinely religious since their motives are seen as antithetical to authentic spirituality and religiosity. Indeed, this view continues to play a profound role in elite common sense today, particularly in the Hindutva or 'Hindu Chauvinist' discourse. It has therefore also had an influential impact on anti-conversion laws in India. Such 
laws attempt to ban conversions brought about 'by allurement', that is, those based on hopes for material betterment. By outlining these 'theological underpinnings' of India's anti-conversion laws, Roberts manages to illustrate how the presumably secular Indian state thereby distinguishes between legitimate and illegitimate forms of religion and how this distinction happens to correspond with the distinctions between elites and slum dwellers and, hence, between upper castes and Dalits. All this goes to show how certain definitions of religion can be helpful in delineating one's object of inquiry but can also be epistemologically misleading and politically problematic.

Religion and modernity. Many introductory courses on the study of religion are based on performative self-contradiction. On the one hand, the curriculum, as well as universities' disciplinary structures, distinguishes the study of religion, politics, economics, and so forth. On the other hand, within the anthropological study of religion, students are often taught that it is hard to delineate where religion starts and where it ends and that societies are not as 'functionally differentiated' as they appear at first sight—-that politics, economics, and religion intersect and often are inseparable. To my mind, both are true on different levels. In one sense, Talal Asad (2003) is right to highlight that modernity gained its hegemony as a political goal that had far-reaching practical consequences, such as attempts to further establish functionally differentiated societies in many parts of the world. Consequently, religion is meant to be separated from politics and at times even relegated to the private realm of individual belief. In another sense, Bruno Latour (1993) is right that 'we have never been modern' since a closer (ethnographic) look generally reveals that this goal was not realized to the degree that modernist discourses suggest. Rather than a priori postulating or precluding the independence of a 'religious realm', the challenge is to explore, through detailed empirical studies, how relevant actors (in and outside of academia) attempt to establish, demarcate, escalate, challenge, or live without specific religious and nonreligious configurations (Quack 2014).

Given the discursive and institutionalized power of modernist assumptions concerning the discreteness (and sometimes obsolescence) of religion, discussions about where religion begins and where it ends are initiated early in the course (in week 3), starting with how Max Weber and Émile Durkheim assessed the fate of religion within 'modern societies'. Through an engagement with their different empirical sociological and historical approaches, we contrast Weber's pessimistic evaluation of antagonistic value spheres with Durkheim's assumption that a division of labor will strengthen social integration (Müller 1992). Against this background, we ask (in week 5) how distinct approaches within the study of religion attempt to delaminate a 'religious realm'. We further ask whether anthropological approaches have a peculiar history and stance in terms of such matters, for example, given their traditional emphasis on 'holism' and their engagement with societies that lack equivalents to the modern understanding of religion.

While we return to the differences between disciplinary traditions in many of the later sessions (particularly in weeks 9 to 12), we also try to avoid overly simplistic and homogeneous understandings of disciplinary differences by further discussing distinct approaches within anthropology. In so doing, I introduce (in week 5) Jeanne Favret-Saada's Deadly Words: Witchcraft in the Bocage (1980), ${ }^{10}$ which classically argues that in order to understand witchcraft, you have to become entangled in its fearful and potentially deadly practices in all kinds of ways, for example, by being afflicted or by engaging in sorcery. Gregor Dobler (2015) confronts this argument through an unintended and small-scale restudy of Favret-Saada's research in the north of France. Dobler was surprised to note that he "never once" encountered a "fear to speak about witchcraft" (ibid.), and that Favret-Saada's theory of witchcraft "was remote from the experiences of the people" he lived with (ibid.). On this basis, we discuss in class the methodological differences between Favret-Saada's and Dobler's studies. In particular, we discuss Favret-Saada's 
drastic switch from researching rural witchcraft beliefs through formal interviews as an irregular visitor from Paris to becoming a total insider entangled in witchcraft practices. Dobler, by contrast, entered the field by simply working as a farmhand. He thereby slowly became acquainted with people's lives and the ways in which witchcraft is only one aspect among, and interrelated with, many others (ibid.). ${ }^{11}$

The course then returns to the more abstract questions that had been introduced earlier in the semester. Why should we treat witchcraft practices in particular and religion more generally as distinct realms with clear insider-outsider demarcations? Is religion a sui generis category that refers to an autonomous sphere with distinctive experiences and ways of knowing, to be approached in its own right? Or is such a perspective tenable only on the basis of 'theological' or 'modernist' reasoning? Does the separation of religion from politics, law, and science also remove it from "spaces in which varieties of power and reason articulate our distinctly modern life" (Asad [1993] 2009: 28)?

Moving back and forth between such abstract questions and more pragmatic concerns, the course then looks more closely at the reasons why Roberts conducted his research in ways similar to Dobler's approach. This also furthers our discussion on the implications of different methodological strategies in the study of religion. In this respect, Roberts (2016: 4) notes that most studies of religion focus primarily on ritual contexts and textual practices:

Relatively few look seriously at what people do when they're not "doing" religion, or what they talk about when they're not talking about it. They tell us little if anything about people's everyday struggles, at work and at home. Fewer still have attempted to grasp the systematic connections between religion and everyday life, or to show how what goes on in the street and in the home gives meaning to religion-not just the reverse, as commonly supposed.

An approach that is not only focused on rituals and texts but is primarily concerned with what people actually do in their everyday lives helps to question the supposedly clear-cut borders between religion and non-religious social realms. This does not mean, however, that anthropologists have to ignore hegemonic discourses and larger political developments that, for example, lead to the institutionalization of functionally differentiated social spheres. Indeed, To Be Cared For shows particularly well how a closer look at everyday life based on participant observation can be embedded in and related to a more encompassing assessment of such larger discourses and political developments.

Additionally and interrelatedly, we then discuss (mainly in week 6) how Roberts's (2016) ethnography challenges seemingly straightforward distinctions between religious traditions. Through the ethnography, the students come to an understanding of the degree to which it is problematic to argue that Christians and Hindus are distinct communities in Anbu Nagar (ibid.: 153). Indeed, 'slum Christianity' and 'slum Hinduism' are in many respects more similar to each other than 'slum Christianity' is similar to 'elite Christianity' or 'slum Hinduism' to 'elite Hinduism' (ibid.). Our respective discussions on the relationships between 'global Christianity' and 'local Christianities' build on students' existing knowledge, making them realize how little they know about the plurality of beliefs, practices, and ways of life that are labeled as 'Christian' around the globe. We again return to modernist assumptions about religion, for example, by discussing 'exclusivist' understandings of religion that see people as either Christian or Hindu. But who says that 'syncretism' is an exception to the rule? Who sets these rules? And why?

Different approaches and the canon. What do different disciplinary approaches enable scholars to see and understand? What are their blind spots and other shortcomings? Similar to the 'case study model', the 'monograph model' tries to answer such questions by looking at empirical 
data through the lenses of particular approaches. With respect to the ethnography To Be Cared For, this works particularly well with approaches that are explicitly applied or discussed in the text or where I can make meaningful connections to the ethnography. This is the case with anthropological (particularly week 4), textual, comparative, economic, and sociological (particularly week 5), historical and genealogical (particularly week 9) approaches, as well as those labeled as material religion, aesthetics of religion, phenomenology, and gender (particularly week 10), and to some degree the study of secularity and non-religion (week 11). But there are, of course, also influential approaches that I am unable to meaningfully connect to this particular ethnography. This is a significant disadvantage of this teaching model. For example, I think an introductory course on the study of religion should also address psychological and cognitive-evolutionary approaches (week 12), given their growing influence within the field. The only way I manage to relate these approaches to the chosen ethnography, however, is by reflecting on the reasons why there seem to be no meaningful connections between them.

To better illustrate this point, the following paragraphs briefly demonstrate what I mean by making a 'meaningful connection' between an approach and the ethnography. To do so, I mainly talk about different perspectives on 'caste' (week 6). Scholars working with textual approaches (Indology, in this case) mainly argue that caste is a religious concept specific to Hinduism, which confines the term to the subcontinent (e.g., Dumont [1966] 1980). By contrast, scholars who employ a comparative approach discuss the differences but mainly highlight the similarities between concepts like caste and race (e.g., Berreman 1979). Ethnographic studies, for their part, often emphasize the varied ways caste is understood in different realms of society, for example, by outlining the dissimilar perspectives that distinct social groups have on caste. Roberts's (2016: 66) ethnography is a case in point since he investigates why and how the slum dwellers, "contra both Brahminical ideology and much anthropological theory," did not relate caste differences to religious notions of purity and pollution. Rather, they "conceptualized resource monopolization and domination as in fact the very essence of caste" (ibid.: 65). ${ }^{12}$ Roberts further engages with historical approaches that look at how practices and understandings of caste have changed over time.

On this basis, we discuss (in week 9) genealogical approaches with respect to the discursive and political conditions of contemporary understandings of caste and Hinduism in particular, but also of religion more generally. This also includes the question of how and to what degree the academic study of religion should itself be a central research object in the academic study of religion. The respective arguments are linked to Talal Asad's (1983) repudiation of Clifford Geertz's (1973) influential definition of religion, ${ }^{13}$ and Asad's ([1993] 2009: 18) suggestion that we turn our attention to the discourses and institutional conditions that shape our understanding of religion to enable "questions that are at once less tendentious and more interesting."

Through this discussion, students learn, on the one hand, to debate whether the concept of religion itself-the way it is likely to be understood by most in the classroom-is a rather recent phenomenon with a distinct Christian as well as post-colonial history. On the other hand, it is helpful to base such debates on empirical studies, for example, on questions about the degree to which contemporary understandings of caste and Hinduism are colonial 'constructions' or 'inventions' (Lorenzen 2006). With respect to caste, we then debate how Roberts (2016: 111-151) uses genealogical insights in his discussions of why and how those who are today called Dalits have not always been seen as Hindus, and how and why high-caste Hindus began to argue for the inclusion of former 'untouchables' into Hinduism around the turn of the twentieth century.

On this basis, the course engages with more recent debates on the problems with canonical texts and the ways and degrees to which syllabi and academic life more generally should be decolonized. Accordingly, we return to our problematizations of terms like 'primitive religion', 
'magic', 'ritual', 'superstition', and 'animism' (in sessions 2 and 3), and engage with the relationships between anthropologists, missionaries, and colonial authorities by discussing, for example, how colonialism shaped classic works, such as those by Evans-Pritchard (in session 4). We discuss the impact and the implications of debates around writing culture, reverse anthropology, anthropology at home, studying up, genealogical and post-colonial approaches, and the proposed blurring of disciplinary boundaries. We ask whether and to what degree anthropologists nevertheless continue to study the apparently 'irrational beliefs' and 'exotic rituals' of Others, and whether they are thereby part of an ongoing process of colonization that implies forms of epistemic and symbolic violence. And we reconsider the composition of the syllabus in this light. Why does this course engage with the so-called classics, mainly those of dead white men with impressive beards, and reproduce a stipulated canon nevertheless? What voices are thus marginalized, silenced, ignored, or excluded? Should these voices be included in the canon, or is the very idea of a 'canon' problematic?

\section{Conclusion}

This article has combined reflections about personal teaching experiences with a more general analysis of teaching possibilities to address questions about how students are introduced to the academic study of religion. How should instructors conceptualize introductory courses? How should they choose, arrange, and interrelate distinct voices and debates? How can an abstract overview be provided without losing sight of real-life concerns?

It started with an exploration of the ways in which books that introduce the anthropological study of religion are structured. On this basis, it outlined why it is helpful to combine several structural logics by engaging, for example, with disciplinary history, key terms, and different approaches within the study of religion. Against this background, the article contends that the most productive approaches draw upon a recurring empirical basis. Instructors thereby do not have to choose between a chronological or a topics-based system, or between theory or ethnography. Instead, specific topics and approaches can and ought to be situated in the history of the discipline. Ethnographies can then be assessed by drawing on theories, just as the analytical potential of theories can only become clear when they are confronted with the empirical world.

How such a mixture of several structural logics works in situ was illustrated through two exemplary course models for an introductory course on the academic study of religion: the 'case study model' and the 'monograph model. The first model draws on one case study to demonstrate the possibilities and shortcomings of different approaches to the study of religion (economic, genealogical, cognitive, aesthetic, etc.). One of its advantages is that discrete approaches can be compared to each other through the same object of inquiry. One specific empirical example or 'case' is examined through many different lenses, and students learn how a single case can be presented and understood in distinctive ways. The second model is structured around a monograph, which is used to introduce the history of the study of religion as well as a set of its key themes, scholars, and approaches. How this can be put into practice was further explicated through a short and illustrative description of three cross-cutting themes that focus on questions related to different definitions of religion and modernity as well as the epistemological and political implications of specific approaches and ideas of a canon. A key advantage of this approach is the engaging nature of the ethnography.

Both models enable instructors to develop a course where the whole composition is greater than the sum of its individual sessions. The problem-oriented narrative-based on a single example or 'case' like the hajj, or on an engaging and multi-layered ethnography like To Be 
Cared For-establishes a thematic and narrative identity that interrelates different sessions into a coherent whole and also adds an extra level to the teaching outcome of individual sessions. Both models also try to sensitize students to the ways in which certain insights are preconfigured by how an object of inquiry is approached in the first place. This learning outcome is substantiated by situating different approaches within specific historical, regional, and disciplinary discourses and the respective politics of knowledge. All this together should enable students to enter the academic study of religion as accepted representatives of their discipline and nurture their intellectual curiosity to explore the field further.

In sum, the recurring empirical case study or ethnography enables instructors to introduce key terms, historical developments, and different approaches, not only in the abstract and independently of each other, but also in real-life experiences and interrelated themes. This emphasis, along with the overarching problem-oriented narrative that is threaded throughout each session, is a helpful didactic and an important argumentative leitmotif for any introductory course to the study of religion. It helps to arrange and accentuate distinct voices and approaches throughout the multi-voiced history of roughly 150 years of scholarly debate and thereby hopefully enables and motivates students to shape the academic study of religion in the decades to come.

\section{ACKNOWLEDGMENTS}

I am very happy to acknowledge the insights furthered by Sondra Hausner, Michael Lambek, Eva Spies, and Jens Kugele during a "Teaching Religion" workshop at the University of Zurich in 2017, where we shared our syllabi and reflected on the ways we teach with a focus on key learning objectives and didactics. Furthermore, I want to thank the following people for stimulating conversations and for their helpful comments on previous versions of this text: Amelie Blom, Simon Coleman, Jacob Copeman, Katyayani Dalmia, Peter Finke, Mareile Flitsch, John Hagström, Dominik Müller, Emanuel Schäublin, Mascha Schulz, and-above all—Stefan Binder and Jens Kugele, plus the two anonymous reviewers.

JOHANNES QUACK is a Professor of Social Anthropology at the University of Zurich. He is the author of Disenchanting India: Organized Rationalism and Criticism of Religion in India (2012), and co-editor of The Problem of Ritual Efficacy (2010), Religion und Kritik in der Moderne (2012), Asymmetrical Conversations: Contestations, Circumventions and the Blurring of Therapeutic Boundaries (2014), Religious Indifference (2017), and The Diversity of Nonreligion: Normativities and Contested Relations (2019). Since 2014 he has co-edited the book series "Religion and Its Others: Studies in Religion, Nonreligion, and Secularity" published by De Gruyter. E-mail: johannes.quack@uzh.ch

\section{NOTES}

1. This is a far-reaching observation that leads to further questions. What would be a suitable venue for such concerns? Why are questions related to teaching not a central part of the assessments, hiring processes, professional societies, journals, conferences and other academic bodies, practices, venues and events? While there is a lot of lip service with regard to the importance of teaching, publications count in the end. Therefore, it is extremely laudable and exemplary that this journal occasionally 
features a section specifically dedicated to teaching. We need more institutionalized and recognized forms of exchange for these matters.

2. There are helpful texts on related matters, such as textbooks for teaching the anthropology of religion (Day and Coleman 2016) and the sociology of religion (Day 2019).

3. This section is based on a revision of Quack (2017).

4. Lambek (2008) also illustrates that there are, of course, many idiosyncratic ways to further organize such a book. Rather than drawing on more common key notions or topics in the study of religion, he separates the texts under headings such as "Poiesis: The Composition of Religious Worlds," "Praxis: Religious Action," and "Historical Dynamics: Power, Modernity, and Change."

5. It would be worthwhile to compare and discuss the various teaching traditions, norms, and normativities that are prevalent in different disciplines, countries, and universities. For example, the so-called Bologna Process involved highly contested agreements between European countries related to higher education standards. These are part of even larger processes of professionalization, bureaucratization, institutionalization, and audit culture in academia. Such an analysis, however, is beyond the scope of this article.

6. This word is mainly used by the slum dwellers and has no strong negative associations in the local context.

7. Roberts (2016) uses the terms 'Indian middle class' and (social and economic) 'elites' interchangeably for those Indians who share a distinctive modern and pan-Indian culture, a strong sense of national identity, and the belief in the middle class's own moral leadership.

8. This might sound overly praising to some readers, but all reviewers of the book-which won the Society for Hindu Christian Studies Book Prize, the Association for Asian Studies' Bernard S. Cohn Book Prize, and the Society for Hindu Christian Studies' Best Book in Hindu-Christian Studies (History/ Ethnography) - beat the same drum.

9. Roberts (2016: 116) adds that he would not argue that those who assume that conversion is socially disruptive in India today and those who propose a 'theological nominalism' are conscious disciples of Durkheim, but "merely that they are partaking of a sedimented modernist common sense of which he is the most famous proponent."

10. For the French version of this volume, see Favret-Saada ([1977] 1994).

11. Further discussions may also address-as Amelie Blom pointed out to me-the degree to which both scholars are "putting into the object the principles of [their] relation to the object" (Bourdieu 1990: 52).

12. Like many scholars before him, Roberts (2016: 62) wonders on this basis "whether the caste-class distinction is theoretically sound" in this context.

13. Lebner's (2016) accessible and engaging discussion brings together many of my concerns in this respect.

\section{REFERENCES}

Asad, Talal. 1983. “Anthropological Conceptions of Religion: Reflections on Geertz.” Man (n.s.) 18 (2): 237-259. https://doi.org/10.2307/2801433.

Asad, Talal. (1993) 2009. “The Idea of an Anthropology of Islam.” Qui Parle 17 (2): 1-30. https://www. jstor.org/stable/20685738.

Asad, Talal. 2003. Formations of the Secular: Christianity, Islam, Modernity. Stanford, CA: Stanford University Press.

Berreman, Gerald D. 1979. Caste and Other Inequities: Essays on Inequality. Meerut: Folklore Institute. Bielo, James S. 2015. Anthropology of Religion: The Basics. London: Routledge.

Boddy, Janice, and Michael Lambek, eds. 2013. A Companion to the Anthropology of Religion. Malden, MA: John Wiley \& Sons.

Bourdieu, Pierre. 1990. The Logic of Practice. Trans. Richard Nice. Stanford, CA: Stanford University Press.

Bowie, Fiona. 2005. The Anthropology of Religion: An Introduction. 2nd ed. Oxford: Wiley-Blackwell. 
Day, Abby. 2019. “Textbooks for Teaching the Sociology of Religion.” Religion 49 (2): 296-307. https:// doi.org/10.1080/0048721X.2018.1505112.

Day, Abby, and Simon Coleman. 2016. “Textbooks for Teaching the Anthropology of Religion: A Review.” Religion 46 (2): 209-220. https://doi.org/10.1080/0048721X.2015.1074406.

Dobler, Gregor. 2015. "Fatal Words: Restudying Jeanne Favret-Saada." Anthropology of This Century 13, May. http://aotcpress.com/articles/fatal-words-restudying-jeanne-favretsaada.

Dumont, Louis. (1966) 1980. Homo Hierarchicus: The Caste System and Its Implications. Rev. ed. Trans. Mark Sainsbury, Louis Dumont, and Basia Gulati. Chicago: University of Chicago Press.

Durkheim, Émile. (1912) 2001. The Elementary Forms of Religious Life. Abridged ed. Trans. Carol Cosman. New York: Oxford University Press.

Eller, Jack David. 2015. Introducing Anthropology of Religion. 2nd ed. New York: Routledge.

Eriksen, Thomas Hylland. (1995) 2015. Small Places, Large Issues: An Introduction to Social and Cultural Anthropology. 4th ed. London: Pluto Press.

Favret-Saada, Jeanne. (1977) 1994. Les mots, la mort, les sorts [Words, death, spells]. Paris: Gallimard.

Favret-Saada, Jeanne. 1980. Deadly Words: Witchcraft in the Bocage. Trans. Maison des Sciences de l'Homme and Cambridge University Press. Cambridge: Cambridge University Press.

Geertz, Clifford. 1973. The Interpretation of Cultures: Selected Essays. New York: Basic Books.

Goody, Jack. 1961. "Religion and Ritual: The Definitional Problem." British Journal of Sociology 12 (2): 142-164. http://dx.doi.org/10.2307/586928.

Lambek, Michael, ed. 2008. A Reader in the Anthropology of Religion. 2nd ed. Malden, MA: Blackwell Publishing.

Latour, Bruno. 1993. We Have Never Been Modern. Trans. Catherine Porter. Cambridge, MA: Harvard University Press.

Lebner, Ashley. 2016. "The Anthropology of Religion: Historical and Contemporary Trends." In Religion: Social Religion, ed. William B. Parsons, 235-252. Farmington Hills, MI: Macmillan Reference.

Lorenzen, David N. 2006. Who Invented Hinduism? Essays on Religion in History. New Delhi: Yoda Press.

Morris, Brian. 1987. Anthropological Studies of Religion: An Introductory Text. Cambridge: Cambridge University Press.

Morris, Brian. 2006. Religion and Anthropology: A Critical Introduction. New York: Cambridge University Press.

Müller, Hans-Peter. 1992. "Gesellschaftliche Moral und individuelle Lebensführung: Ein Vergleich von Emile Durkheim und Max Weber" [Social morality and individual life conduct: A comparison of Émile Durkheim and Max Weber]. Zeitschrift für Soziologie 21 (1): 49-60.

Pals, Daniel L. 2006. Eight Theories of Religion. 2nd edition. New York: Oxford University Press.

Quack, Johannes. 2014. "Outline of a Relational Approach to 'Nonreligion." Method \& Theory in the Study of Religion 26 (4-5): 439-469. https://doi.org/10.1163/15700682-12341327.

Quack, Johannes. 2017. "Religionsethnologie" [Anthropology of religion]. In Ethnologie: Einführung and Überblick [Social/cultural Anthropology: Introduction and overview], 9th ed., ed. Bettina Beer, Julia Pauli, and Hans Fischer, 183-199. Berlin: Dietrich Reimer Verlag.

Roberts, Nathaniel. 2016. To Be Cared For: The Power of Conversion and Foreignness of Belonging in an Indian Slum. Oakland: University of California Press.

Saler, Benson. 1993. Conceptualizing Religion: Immanent Anthropologists, Transcendent Natives, and Unbounded Categories. Leiden: E. J. Brill.

Spiro, Melford E. 1966. "Religion: Problems of Definition and Explanation." In Anthropological Approaches to the Study of Religion, ed. Michael Banton, 85-126. London: Tavistock.

Tylor, Edward. (1871) 2008. "Religion in Primitive Culture." In Lambek 2008, 23-33.

Vásquez, Manuel A. 2010. More Than Belief: A Materialist Theory of Religion. New York: Oxford University Press. 